\title{
Early Childhood Education During the Covid-19 Pandemic in Indonesia
}

\author{
Desvi Wahyuni ${ }^{1, *}$, Rudiyanto ${ }^{2}$ \\ ${ }^{1,2}$ Department of Early Childhood Education, School of Postgraduate, Universitas Pendidikan Indonesia \\ ${ }^{*}$ Corresponding author. Email: desvi.wahayuni@upi.edu
}

\begin{abstract}
This article aims to see the extent to which the quality of learning resulted from collaboration between parents and teachers during the Covid-19 pandemic. Given that the quality of learning is an important thing that should be considered when the teaching and learning process occurs, both when the teaching and learning process is carried out at school or at home, such as when the Covid-19 pandemic occurred. With the Indonesian Government's appeal regarding physical distancing and social distancing, the teaching and learning process is carried out from home (learn from home) and causes a learning process that involves collaboration between parents and teachers. The difference in background between parents and teachers makes the quality of learning not the same when it is done at school and at home. The findings obtained through data collection methods in the form of interviews and literature reviews are the limitations of learning media at home and the lack of interaction between teachers and children which results in learning from having limitations in terms of observing and assessing children's abilities.
\end{abstract}

Keywords: Covid-19, learning from home, quality of learning.

\section{INTRODUCTION}

As a UNESCO member country, Indonesia through the Ministry of Education and Culture (Kemdikbud) has formed a special unit tasked with assessing the quality of Early Childhood Education (ECE) in terms of facilities, administration and learning. The assessment is based on eight ECE standards consisting of standards for developmental achievement levels, content standards, process standards, facilities and infrastructure standards, management standards, financing standards, and education assessment standards [1]. The purpose of this assessment is to be able to see the quality and quality of institutions that have an impact on children's development and abilities [2] and see the ability of teachers in managing teaching and learning activities [3].

Then, what about the quality of learning carried out during a pandemic like today? With the appeal to stay at home, the educational process continues from home or the term better known today is learn from home (LFH). In the process of learning from home, teaching and learning activities are carried out between teachers and students by utilizing existing technological facilities, such as the use of the zoom cloud meeting application, google classroom, WhatsApp group, Facebook group, and so on with the aim of channelling learning material from the teacher. to the pupil. With all the sophistication of technology today, it is not difficult to transfer knowledge from teacher to student. However, the existence of different backgrounds between teachers and parents coupled with the condition of parents who have to work from home or work from home, raises new questions about the distance learning process through technology can guarantee the quality of learning and education, especially education for early childhood. Then how about the fulfilment of media and other learning facilities when teaching and learning activities are carried out from home?

Furthermore, to answer these questions using interview methods and literature studies, this article will discuss some important points from the learn from home activity or distance learning from various available sources and the quality of learning that results when the interaction between teachers and students is carried out from their own homes.

\section{TEACHERS-PARENTS COLLABORATIVE LEARNING}

In Indonesia, the spread of covid-19 was first discovered in early March 2020 and infected two residents in Depok, West Java [4]. Quoted from the 
official website of the National Board for Disaster Management of Covid-19 Task Force, to date $(07 / 04 / 2020)$ there are 2,738 positive patients with coronavirus, 204 recovered patients, and 221 patients who died from this virus. To overcome the increasingly widespread spread of covid-19, the President of the Republic of Indonesia, Ir. Joko Widodo in a conference at the Bogor Palace on March 15, 2020, urged the public to carry out work, study and worship activities from home [5] or better known as work from home and learn from home. This aims to make people do social distancing or limit social interaction so that the spread of this virus can be suppressed [6].

As the Indonesian President's appeal regarding social distancing, schools as an educational institution that carries out the learning process should continue to carry out teaching and learning activities as usual. In the scope of Early Childhood Education or commonly referred to as ECE, schools will provide facilities in the form of facilities and infrastructure that can be used in the implementation of activities in education, care and protection for early childhood [7] both for indoor activities such as tools. educational games or for outdoors or outdoor play facilities. In addition to facilities and infrastructure, educational institutions must make plans for the implementation of daily learning or RPPH which will be carried out and implemented by the teacher [8].

Then, what about teaching and learning activities amid the covid-19 outbreak? In the midst of the covid-19 outbreak, teaching and learning activities are carried out by distance learning or learn from home, in accordance with the appeal of the President of the Republic of Indonesia, Ir. Joko Widodo, so that people carry out work, study and worship activities from home [5] so that everything needed for the teaching and learning process is fulfilled by parents as educators at home. Through a short interview through the WhatsApp application to several teachers who carry out teaching and learning activities from their homes, it is stated that this activity has been going on since an appeal from the local district or city government was issued by the respective Education and Culture Office.

In current conditions, in accordance with the government's recommendation to Stay at Home, teaching is also done from home. For the media used in delivering information, currently only the WA application (WhatsApp) is used. Yesterday I wanted to try the Zoom application and I instructed parents to install (the application) but the response was lacking, possibly because the availability of internet facilities in each house is different $(8 / 4 / 2020)$.

Said Mrs. Mawar, who teaches at Melati Kindergarten. The same thing was conveyed by Mrs. Betha who taught at Kindergarten Anggrek.
When there was a policy of learning from home by means of online / online learning, I invited parents to cooperate in delivering learning materials through the WA (WhatsApp) group of the parent class. That is the right place for me to deliver material and share the problems faced by parents in accompanying children to study at home (9/4/2020).

From the two answers delivered by the kindergarten teachers, they followed the call to stay at home and carry out learning from home activities by involving communication media, in this case using the WhatsApp application. In delivering learning materials, the teachers explain to the parents about the existing material, starting from the RPPH for daily activities, the media used, the learning rules, to how to report activities. This is as stated in Circular Number 4 of 2020 [9] concerning the Implementation of Education Policies in an Emergency Period of the spread of the second covid-19 point which states that the teaching and learning process is carried out through online or distance learning.

In delivering learning materials, I will provide material points summarized from the RPPH. Then the parents will deliver the material to the child at home. I also provide some provisions that must be considered while studying at home, so that parents continue to control the child's learning process" (Mrs. Betha, 9/4/2020).

From this statement, learning from home activities are the same as teaching and learning activities at school. The teacher still delivers points of learning material or activity indicators, only if the delivery of these points is carried out directly through activities that will be carried out without involving parents as supervisors of activities directly.

Teaching materials or materials are prepared in advance in the form of a weekly syllabus. in it contains aspects of development, activities, tools and materials used. The syllabus is given at the beginning of the week on Monday morning. then every day you are reminded of the daily activities that will be carried out on that day via messages in the WhatsApp group (Mrs. Mawar, $8 / 4 / 2020)$

In the activity of learning from home, parents' contributions are needed. Parents not only serve as supervisors of activities, but also serve as guides and teachers during the child's learning process.

In the distance education process, the role of parents is more precisely as a companion in every child's activities. Even for certain types of activities parents are partners / collaborators of children. For certain activities such as memorizing short letters, daily prayers and hadiths, the practice of praying parents acts as a teacher by teaching reading according to what is learned in kindergarten (Mrs. Mawar,8/4/2020). 
The same thing was conveyed by Mrs. Betha through her WhatsApp message.

In the learning process at home, the role of parents is very important. Apart from being a parent, there is a dual role of being a teacher during the learning process at home. The material that I pass on to parents they will pass on to their children. There is a positive impact in the learning process at home, one of which is that parents pay more attention to their children's learning activities and can find out the ability / development of their respective children. Even though it's only been a few weeks of studying at home, some parents have complained about the difficulty of becoming a teacher (9/4/2020).

From the two explanations above, the role of parents is very important during the Covid-19 pandemic. Parents like it or not have to participate in conducting and guiding the children's learning process so that parenting is needed. Parents will have a lot of interaction with children when guiding the child's learning process, giving full attention to the child so that they can find out the extent of their child's development. From this learning from home activity, parents will spend a lot of time playing and learning with their children. This means that the positive side of this pandemic is to strengthen the relationship between parents and children and to restore the fact that home is the child's first socialization area. The communication between parents and children will be better and tighter than before.

If in normal circumstances, the involvement of parents in the learning process of school children will have a positive impact. Hawes and Jesney [10] explain that parental involvement is the participation or participation of parents in the educational process carried out by children. The process of parental involvement in learning will have a contribution in achieving aspects of development in children [11], so that in the normal educational process, the involvement of parents will improve the quality of the learning process both at home and at school.

\section{LEARNING QUALITY DURING THE COVID-19 PANDEMIC}

After understanding the LFH system that involves the participation of parents in the delivery of learning material, of course, it will raise new questions regarding the quality of the resulting learning. Then, what about the quality of learning produced during the Covid-19 pandemic? Unlike the teaching and learning activities carried out in schools, teaching and learning activities at home when viewed from the use of learning materials and media will certainly be very different. Keep learning materials and media at home as simple as possible so that their availability can be fulfilled, so that when viewed from the facilities and infrastructure used do not meet the existing quality compliance standards.

The facilities provided by the school for learning activities at school are certainly different from learning activities at home. So, during the process of learning activities at home, use the makeshift facilities in each house. If the facility is not available at home, the guardian of the student should try to buy or borrow from a friend or neighbour who is near the house (Mrs. Betha, 9/4/2020).

It means to fulfil the facilities and infrastructure when teaching and learning activities are carried out at home, parents can use makeshift facilities or those around them. If there is no, parents should look for other ways so that teaching and learning activities can still be carried out as they should.

When teaching and learning activities are carried out in schools, of course the school provides facilities that support the learning process. As for the current condition, learning activities are modified by making slight changes by considering the condition of the child at home. The teacher arranges activities that can be done at home, even if using the media, the media is in their respective homes (Mrs. Mawar, 8/4/2020).

In order to achieve learning objectives and fulfilment of assessment indicators, teaching and learning activities will be changed according to the situation and conditions of the house. This is also in line with the theory of curriculum development where the activities to be carried out by teaching and learning activities should be carried out according to existing socio-cultural conditions [12]. So that during a pandemic like today, institutions, especially teachers, should prepare learning materials that can be adapted to the conditions and learning situations of children.

For children's assignments in the form of worksheets the teacher has prepared for the week. Technically, parents come to school on Monday morning to take on children's assignments and submit children's assignments in the previous week to be assessed by the teacher. Why can this be done? because it happened that our kindergarten was located in a housing complex, most of our students were in an area that was not too far away so they could come. Giving soft files related to assignments was also sent via WhatsApp group messages, but parents prefer to take them directly by coming to school. In addition, to get around the inequality of equipment owned by parents at home, the activities are more emphasized on developing the child's life skills from home (Mrs. Mawar, 8/4/2020).

As previously explained, the educational process is carried out by utilizing existing technological media so that the delivery of delivery material is done online or in supporting applications, even though in the learning 
process, learning media facilities use makeshift tools. In fulfilling the quality of learning as seen from the accreditation standards, good quality learning will be supported by appropriate facilities and infrastructure. So that in the covid-19 pandemic situation the quality of education when viewed from the point of view of facilities and infrastructure as well as learning materials can be said to be sufficient because of the availability of learning facilities around the house and learning materials delivered using communication tools, in this case the WhatsApp application.

Even though the two standards mentioned, the quality of learning is said to be good, this does not necessarily satisfy the teacher in meeting the quality of existing learning. There is a missing educational process when teacher and student interactions are only carried out through online media.

The quality of learning carried out at school and at home is of course not the same, if the quality is interpreted as the same value / measure then distance learning, especially for kindergarten, is considered very unsatisfactory. We remember that in the assessment / evaluation in kindergarten, it is not only result-oriented but the process being assessed. In this case there is a missing part, namely the "process". The teacher cannot directly see the process in every child's activity. Although the form of reports from parents requested varies, some are in the form of photos, voice notes, or videos. What I feel myself, I still feel lacking because a part is missing, namely the process earlier (Mrs. Mawar, 8/4/2020).

The answer given by Mrs. Mawar shows the dissatisfaction of a teacher in carrying out the distance learning process. Direct interaction between teachers and students is very important in the educational process. Given that education is a process of humanizing humans, returning humans to their full human nature permanently, making the educational process not only a process of transferring knowledge or knowledge, but also carrying out social interactions where this interaction is expected to present the character and value of an educational process.

The teacher doesn't directly see the process. because learning is a process of interaction, when the interaction is lost, there is a missing part that is also irreplaceable (Mrs. Mawar, 8/4/2020).

The same thing was conveyed by Mrs. Betha, that the quality of direct learning carried out in school was very different from the quality of learning done remotely or learned from home.

The quality of distance education is not the same as the quality of face-to-face education. Teachers cannot convey directly to children about the material being studied. The teacher cannot fully control the child's learning process. Teachers also cannot know the development of children's abilities in detail (Mrs. Betha, 9/4/2020).

From the answers above, it can be seen that the teacher's role is not only as someone who teaches and transfers knowledge, the teacher also acts as a figure who pays attention and knows every development that occurs to students. In line with this, [13] states that an educator or teacher does not only convey learning material to children, but teachers also need to pay attention to the problems that are being faced by children and children's development. Ki Hajar Dewantara said that the position of a teacher was not a dictator but someone who volunteered to form a community in order to be able to defend the nation [14]. Suyanto and Hisyam [15] also state that teachers are the party who has responsibility for the quality of education, because the presence and professionalism of a teacher will have an influence to determine and realize the ideals of national development, especially the national education program.

In addition to the limited interaction between teachers and students in the learning process, the quality of learning during the pandemic is also influenced by limited media and learning methods. The existence of differences in methods and media between school and home also provides major changes in the delivery of learning material to children, so that aspects of development in children cannot be carried out optimally [16], [17], [18].

\section{CONCLUSION}

From the explanation of the literature study and the results of interviews conducted with ECE teachers, it was found that with the Covid-19 pandemic the learning process was carried out from home by involving interactions between parents and teachers. The online learning is conveyed by the teacher to parents so that parents can guide, supervise and report the results of learning carried out by children at home. Even though there has been collaboration between teachers and parents in learning from home activities, this does not necessarily mean that the quality of learning carried out at school and at home is the same. With the limited media and learning resources, learning activities return to daily activities using the media and learning resources available at home. So that indirectly, this is only done inside the house without involving many activities that hone children's thinking skills. In addition, with the learn from home appeal, the interaction between students and teachers is limited, so there are limitations in some things that should be done by the teacher, such as assessments and observations made by the teacher.

\section{REFERENCES}

[1] Badan Akreditasi Nasional Pendidikan Non-Formal. Instrumen akreditasi pendidikan anak usia dini 
(PAUD) [Internet]. 2014 [cited 2020 Oct 25]. Available from: www.banpnf.or.id.

[2] Winterbottom C, Piasta SB. Does accreditation matter? school readiness rates for accredited versus nonaccredited child care facilities in florida's voluntary pre-kindergarten program. Journal of Research in Childhood Education. 2015;29(1):6072.

[3] Burns SC. Achieving quality in early childhood education in the Eastern Caribbean depends on teacher preparation. Early Child Development and Care. 2018;188(9):1246-5.

[4] Yunita NW. Penyebab, asal mula, dan pencegahan virus corona di indonesia [Internet]. Detik News. 2020 [cited 2020 Nov 8]. Available from: https://news.detik.com/berita/d-4956764/penyebabasal-mula-dan-pencegahan-virus-corona-di indonesia.

[5] Ratriani VR. Jokowi instruksikan bekerja dari rumah, ini arti work from home [Internet]. Kompas. 2020 [cited 2020 Nov 8]. Available from: https://www.kompas.com/tren/read/2020/03/16/195 035165/jokowi-instruksikan-bekerja-dari-rumahini-arti-work-from-home.

[6] Australian Government Department of Health. Physical distancing for coronavirus (COVID-19) [Internet]. Australian Government Department of Health. 2020 [cited 2020 Nov 8]. Available from: https://www.health.gov.au/news/health alerts/novelcoronavirus-2019-ncov-health-alert/how-to-protectyourself-and-others-from-coronavirus-covid19/ physical-distancing-for-coronavirus-covid-19.

[7] Ministry of Education and Culture of the Republic Indonesia. Peraturan Menteri Pendidikan dan Kebudayaan Republik Indonesia [Internet]. No 137 Indonesia; 2014. Available from: https://luk.staff. ugm.ac.id/atur/bsnp/Permendikbud137/2014 standarnasionalPAUD.pdf.

[8] Ministry of Education and Culture of the Republic Indonesia. Surat Edaran tentang Penyederhanaan RPP [Internet]. 14 Indonesia; 2019. Available from: https://setjen.kemdikbud.go.id/setjen/files/surat/eda ran nomor 14 tahun 2019 tentang penyederhanaan rencana pelaksanaan pembelajaran.pdf.

[9] Ministry of Education and Culture of the Republic Indonesia. Surat Edaran tentang Pelaksanaan Kebijakan Pendidikan dalam Masa Darurat Penyebaran Coronavirus Disease (Covid-19) [Internet]. 4 Indonesia; 2020. Available from: https://www.kemdikbud.go.id/main /blog/2020/03/se-mendikbud-pelaksanaan kebijakan -pendidikan-dalam-masa-darurat-penyebarancovid19.

[10] Padavick J. Parental involvement with learning and increased student achievement. [Doctoral
Dissertation, Walden University]. Minnesota: Walden University; 2010.

[11]Park H, Byun S, Kim K. Parental involvement and students' cognitive outcomes in Korea: Focusing on private tutoring. Sociology of Education. 2011;84(1):3-22.

[12] Sukirman D. Landasan pengembangan kurikulum [Internet]. Landasan Pengembangan Kurikulum. Bandung: Repository UPI; 2007 [cited 2020 Nov 8]. Available from: http://file.upi.edu/direktori/fip /jur._pend._luar_biasa/196209061986011/ahmad_ mulyadiprana/pdf/landasan_kurikulum.pdf.

[13] Alkornia S. Studi deskriptif kompetensi pedagogik dan profesionalisme guru PAUD Dharma Wanita binaan SKB Situbondo. Pancaran. 2016;5(4):14358

[14]Tilaar HA, Nugroho R. Kebijakan pendidikan: Pengantar untuk memahami kebijakan pendidikan dan kebijakan pendidikan sebagai kebijakan publik. Yogyakarta: Pustaka Pelajar; 2016.

[15] Suyanto, Hisyam D. Refleksi dan reformasi pendidikan di Indonesia memasuki milenium III [Internet]. Yogyakarta: Adi Cita; 2000 [cited 2020 Nov 8]. Available from: https://books.google.co.id /books/about/Refleksi_dan_reformasi_pendidikan_ di_Ind.html?id=WgkyAAAACAAJ\&redir_esc $=y$.

[16]Kim YH. Measuring quality of curriculum implementation and teaching in childcare centers using accreditation standards in South Korea. Child Indicators Research. 2014;7(2):387-405.

[17] Naylor H. Outdoor play and play equipment. Early Child Development and Care. 2006;19(1-2):10930.

[18] Qian Y. Equity and quality: Challenges in providing early childhood educational opportunity in China. Australasian Journal of Early Childhood. 2013;38(4):59-65. 